\title{
'N WOORD VOORAF
}

Dit is vir die Redaksie van die Hervormde Teologiese Studies 'n besondere voorreg dat hierdie uitgawe opgedra kan word aan PROF. S. P. ENGELBRECHT, wat kort gelede die ouderdom van sewentig jaar bereik het. Die uitgawe staan hier as 'n eerbewys, as 'n gelukwens, as 'n blyk van dankbare erkentlikheid.

Daar is enorm veel waarvoor ons S. P. ENGELBRECHT kan dank. Dit blyk ook hier en daar uit die artikels wat in hierdie uitgawe verskyn. As kerkgeskiedskrywer, as nougesette wetenskaplike navorser, as ywerige, byna-onvermoeibare versamelaar van argivalia, as hoogleraar en as kerklike leiersfiguur het hy 'n plek in die geskiedenis van die Kerk en van ons volk volgestaan wat nie aan vele beskore is nie. As seun het hy die ou ZuidAfrikaansche Republiek geken en sy ondergang in die, deur Engeland geforseerde oorlog van 1899-1902, meegemaak. Die ontreddering, die swaarkry van ' $n$ volk wat op sy knieë gedwing is, wat tot die bedelstaf toe verarm en byna uitgeroei was, het hy in al die werklikheid daarvan in sy jeugjare ervaar. Die opstaan, die groei en die byna fenomenale ontplooiing van hierdie volk het S. P. ENGELBRECHT ook ervaar. Dit het hy nie net saam ervaar nie maar doelgerig, vashoudend en rigtinggéwend help bewerkstellig. Dit het hy gedoen op die terrein waar hy geroep was tot diens van God en sy medemens-die Kerk.

Daarom het S. P. ENGELBRECHT in die eerste plek sy krag en sy werkywer gegee aan die beoefening van die teologiese wetenskap. Dit het hy gedoen aan die Teologiese Fakulteit Afdeling A van die Universiteit van Pretoria. Daarom is die geskiedenis van daardie Fakulteitsafdeling tot in so hoë mate die geskiedenis van S. P. ENGELBRECHT. Groot is daarom die invloed wat hy gehad het op die wetenskaplike beoefening van die Bybels-reformatoriese teologie in ons land. Groot is die invloed wat hy gehad het op die wetenskaplike kerkgeskiedskrywing in Suid-Afrika. Sonder kennisname van sy groot getal publikasies op hierdie vakgebied is die studie van die Suid-Afrikaanse kerkgeskiedenis onmoontlik. Sy werk is en bly hier 'n maatstaf vir diegene wat saam of na hom op dieself terrein beweeg het en beweeg.

Juis deur sy liefde vir die geskiedenis van Gods Kerk op aarde was S. P. ENGELBRECHT altyd 'n teoloog wat teologie beoefen het terwille van die Kerk. Vanhieruit het sy liefde vir die Ned. Hervormde Kerk ontspring. 'n Liefde wat een van die mooiste eienskappe is wat hom sier, 'n liefde wat sy lewe bepaal het. Vanhieruit vloei voort sy bemoeienisse om die bande met nederlandse Kerk sterk te hou, sy bemoeienisse om voortdurend vir die Kerk alleen die beste te doen en te beoog. 
So, deur hom by voortduring, met al sy enorme werkkrag en ywer, te wy en te bepaal by dié terrein in die lewe waar hy tot diens geroep is, het S. P. ENGELBRECHT sy groot bydrae gelewer tot die groei en ontplooiing van die Kerk en van die teologiese wetenskap in Suid-Afrika, tot heil van die volk.

Aan hierdie man wat soveel gedoen het vir die wetenskaplike beoefening van die Bybels-reformatoriese teologie in Suid-Afrika en wat ook soveel gedoen het vir die Kerk, word hierdie uitgawe opgedra. Laat dit dien as bewys dat die Redaksie van hierdie tydskrif en almal wat hom ken, diep dankbaar is dat ' $n$ man soos S. P. ENGELBRECHT aan die Kerk en die teologiese wetenskap in Suid-Afrika gegee is.

A. D. Pont. 